\title{
Homeobox Protein Hox-B4
}

National Cancer Institute

\section{Source}

National Cancer Institute. Homeobox Protein Hox-B4. NCI Thesaurus. Code C105437.

Homeobox protein Hox-B4 (251 aa, $28 \mathrm{kDa}$ ) is encoded by the human HOXB4 gene.

This protein plays a role in anterior-posterior patterning during embryonic development. 